\title{
Multiple Brain Abscesses of Odontogenic Origin. May Oral Microbiota Affect Their Development? A Review of the Current Literature
}

\author{
Nicola Montemurro ${ }^{1,2} \mathbb{D}$, Paolo Perrini ${ }^{1,2} \mathbb{D}$, Walter Marani ${ }^{3}$, Bipin Chaurasia ${ }^{4}$, Massimo Corsalini ${ }^{5}(\mathbb{D}$, \\ Antonio Scarano ${ }^{6}(\mathbb{D})$ and Biagio Rapone ${ }^{7, *(D)}$
}

1 Department of Neurosurgery, Azienda Ospedaliera Universitaria Pisana (AOUP), 56100 Pisa, Italy; nicola.montemurro@unipi.it (N.M.); paolo.perrini@unipi.it (P.P.)

2 Department of Translational Research and of New Surgical and Medical Technologies, University of Pisa, 56126 Pisa, Italy

3 Unit of Neurosurgery, Mater Dei Hospital, 70121 Bari, Italy; wmarani1@gmail.com

4 Department of Neurosurgery, Bangladesh State Medical University, Dhaka 1205, Bangladesh; troexa@gmail.com

5 Interdisciplinary Department of Medicine, University of Bari, 70121 Bari, Italy; massimo.corsalini@uniba.it

6 Department of Oral Science, Nano and Biotechnology and CeSi-Met University of Chieti-Pescara, 66100 Chieti, Italy; ascarano@unich.it

7 Department of Basic Medical Sciences, Neurosciences and Sense Organs, "Aldo Moro" University of Bari, 70121 Bari, Italy

* Correspondence: biagio.rapone@uniba.it

check for updates

Citation: Montemurro, N.; Perrini, P.; Marani, W.; Chaurasia, B.; Corsalini, M.; Scarano, A.; Rapone, B. Multiple Brain Abscesses of Odontogenic Origin. May Oral Microbiota Affect Their Development? A Review of the Current Literature. Appl. Sci. 2021, 11, 3316. https://doi.org/10.3390/ app11083316

Academic Editor: Gaetano Isola

Received: 13 March 2021

Accepted: 4 April 2021

Published: 7 April 2021

Publisher's Note: MDPI stays neutral with regard to jurisdictional claims in published maps and institutional affiliations.

Copyright: (c) 2021 by the authors. Licensee MDPI, Basel, Switzerland. This article is an open access article distributed under the terms and conditions of the Creative Commons Attribution (CC BY) license (https:// creativecommons.org/licenses/by/ $4.0 /)$.
Abstract: In the last few years, the role of oral microbiota in the setting of oral diseases such as caries, periodontal disease, oral cancer and systemic infections, including rheumatoid arthritis, cardiovascular disease and brain abscess (BA), has attracted the attention of physicians and researchers. Approximately $5-7 \%$ of all BAs have an odontogenic origin, representing an important pathological systemic condition with a high morbidity and mortality. A systematic search of two databases (Pubmed and Ovid EMBASE) was performed for studies published up to 5 January 2021, reporting multiple BAs attributed to an odontogenic origin. According to PRISMA guidelines, we included a total of 16 papers reporting multiple BAs due to odontogenic infections. The aim of this review is to investigate the treatment modality and the clinical outcome of patients with multiple BAs due to odontogenic infections, as well as to identify the most common pathogens involved in this pathological status and their role, in the oral microbiota, in the onset of oral infections. A multidisciplinary approach is essential in the management of multiple BAs. Further studies are required to understand better the role of microbiota in the development of multiple BAs.

Keywords: brain abscess; odontogenic; dental origin; central nervous system infection; dental infection; cerebral abscess; oral infection; neurosurgery; surgery

\section{Introduction}

Brain abscess (BA), defined as a focal infection within the brain parenchyma, which starts as a localized area of cerebritis and subsequently is converted into a collection of pus within a well-vascularized capsule [1], represents a universal health problem with a high long-term morbidity, and a mortality rate of up to $9.5 \%$ reported in some studies [2-4]. The reported incidence of BAs was estimated at 0.3 to 1.3 cases per 100,000 people per year [5], with a male predominance (ratio resulted from 2:1 to 3:1) and a median age of 30 to 40 years in most pediatric and adult series, although the age distribution varies depending on the predisposing condition leading to the formation of BA [5]. Approximately 5-7\% of all BAs are caused by dental infection and manipulation. Dental procedures in the setting of periodontal disease can provoke focal oral infections. Multiple abscesses account for $5-50 \%$ of all BAs, which are often seen, but not only, in immunocompromised patients and 
are the result of hematogenous spread. Some microorganisms are more common causative than others; a well-known condition, although not fully clarified $[6,7]$.

The human oral cavity contains a very broad range of microorganisms. These microorganisms constitute the human oral microbiota, which represents one of the most complex microbial communities in the human body [8]. Some authors reported about 500 different species and 700 kinds of microorganisms [8], and that all known microorganisms associated with humans are at some time found in the oral cavity as either transient (the majority) or resident (only a few) species [9]. It seems that the bacteria that cause odontogenic infections are generally saprophytes. Some microorganisms are usually more responsible for these illnesses compared to others (in well-known conditions, still to be clarified) [10].

In recent years, the role of oral microbiota in the setting of oral diseases such as caries, periodontal disease, oral cancer and systemic infections has attracted the attention of physicians and researchers [11-15]. There is also evidence that oral microbiota is closely related to some systemic diseases, including rheumatoid arthritis, adverse pregnancy outcomes, cardiovascular disease and BA [16-21]. In addition, a recent study reported the role of saliva and saliva early mediators of oral microbiota, like serum and salivary Galectin3 levels, in predicting periodontitis [21-23]. Patients suffering from severe untreated periodontal disease frequently experience bacteraemia after tooth brushing, flossing and chewing [23]. Frequent bacteraemia and systemic spill of proinflammatory cytokines [24] from periodontal pockets result in the release of leukocyte elastase and acute phase proteins. The link between oral infections and adverse systemic conditions such as multiple BAs has attracted much attention in the research community in the last few years and with it, also the role of oral microbiota and the mechanism underlying its spreading from mouth to brain, through transient bacteremia resulting in bacterial colonization in extra-oral sites. It seems that the composition of primary odontogenic infections reflects the normal oral microbiota and the method of dissemination.

To the best of our knowledge, this is the first review of multiple BAs of odontogenic origin. The aim of this review is to assess the more common pathogens involved in multiple BAs, the possible surgical and medical treatments, the antibiotic therapies taken into account and the role of microbiota in the onset of oral infections and blood dissemination, leading to the development of multiple BAs.

\section{Materials and Methods}

\subsection{Literature Search}

A Pubmed and Ovid EMBASE search was performed to identify articles from the period 1988 to present, relevant to multiple brain abscesses attributed to an odontogenic origin. PRISMA guidelines (Preferred Reporting Items for Systematic Reviews and Metaanalyses) were followed [25]. The key words "multiple brain abscess", "multiple cerebral abscess", "odontogenic", "dental" and "dental origin" were used in both "AND" and "OR" combinations. The key words and the detailed search strategy are reported in Table 1.

Table 1. Search syntax.

\begin{tabular}{cc}
\hline $\begin{array}{c}\text { PubMed Search Accessed on } \\
\text { 5 January 2021 } \\
\text { (42 Articles) }\end{array}$ & $\begin{array}{c}\text { Embase Search Accessed on } \\
\text { 5 January 2021 } \\
\text { (46 Articles) }\end{array}$ \\
\hline (multiple) AND (brain abscess OR brain & $\begin{array}{c}\text { ('multiple') AND ('brain abscess' OR 'brain } \\
\text { abscesses' OR 'cerebral abscess' OR 'cerebral } \\
\text { abscesses OR cerebral abscess OR cerebral } \\
\text { abscesses) AND (odontogenic OR dental OR } \\
\text { dental origin) }\end{array}$ \\
\hline
\end{tabular}

The inclusion criteria were the following: case series or case reports reporting neurological clinical data, pathogens and outcome of patients with multiple BAs due to odontogenic infections. Exclusion criteria were the following: (1) studies published in languages other than English with no available English translations, (2) review articles, (3) case series or 
case report reporting single BA, (4) studies that did not involve human beings, (5) studies with insufficient data, (6) studies not related with this topic.

\subsection{Data Collection}

From each study, we extracted the following: (1) patient's demographics; (2) neurological clinical presentation; (3) number of BAs and their locations; (4) pathogens involved; (5) treatment modality; (6) clinical outcome.

\subsection{Outcomes}

The primary objective of this systematic review was to examine the treatment modality and the clinical outcome of patients with multiple BAs due to odontogenic infections. The secondary objectives were to identify the most common clinical presentation and the most common pathogens involved in this pathological status.

\section{Results}

\subsection{Literature Review}

The database search yielded 88 articles. After the removal of duplicates, 47 articles were eligible for screening. A total of 16 articles met the selection criteria [6,26-40]. Studies included in our systematic review are summarized in Table 2. The search flow diagram is shown in Figure 1. A total of sixteen patients reported multiple BAs due to odontogenic infection, and were included and analyzed in this review [6,26-40].

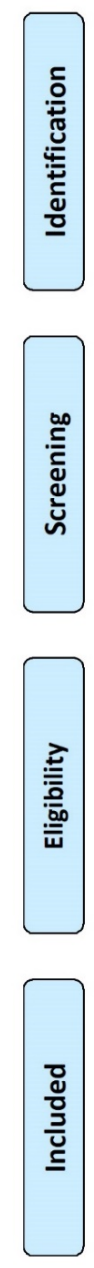

Records identified through

Pubmed database searching ( $n=42$ )

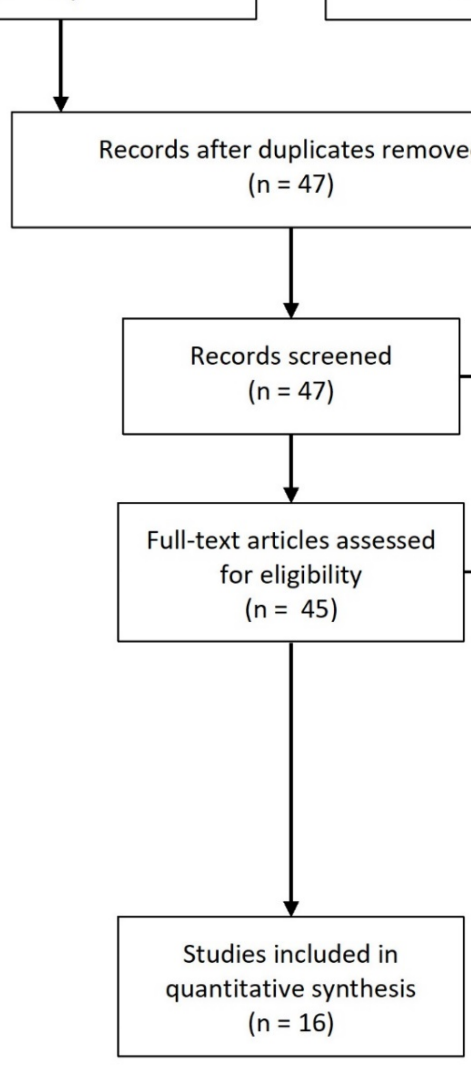

Additional records identified through Ovid EMBASE database searching $(n=46)$

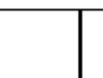

(n)

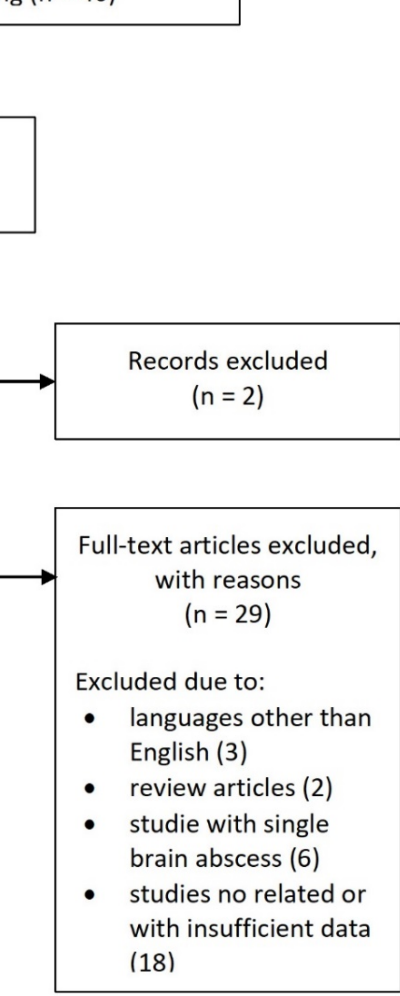

Figure 1. PRISMA flow diagram. 
Table 2. Summary of studies included in the review.

\begin{tabular}{|c|c|c|c|c|c|c|c|c|c|c|}
\hline Authors & Year & Age/Sex & $\begin{array}{l}\text { Neurological } \\
\text { Clinical } \\
\text { Presentation }\end{array}$ & $\mathbf{N}^{\circ}$ of BAs & BAs Location & Pathogens & $\begin{array}{l}\text { Surgical } \\
\text { Treatment }\end{array}$ & $\begin{array}{l}\text { Medical } \\
\text { Treatment }\end{array}$ & $\begin{array}{l}\text { Follow-Up } \\
\text { (Months) }\end{array}$ & Outcome \\
\hline $\begin{array}{c}\text { Marks et al. } \\
\text { [33] }\end{array}$ & 1988 & $26 / \mathrm{M}$ & $\begin{array}{l}\text { confusion and } \\
\text { reduced } \\
\text { consciousness }\end{array}$ & 5 & $\begin{array}{l}\text { Right frontal (3), } \\
\text { right parietal (2) }\end{array}$ & $\begin{array}{l}\text { Streptococcus } \\
\text { viridans }\end{array}$ & - & - & - & Death \\
\hline $\begin{array}{c}\text { Kuijper et al. } \\
{[32]}\end{array}$ & 1992 & $44 / \mathrm{M}$ & right arm paresis & 2 & $\begin{array}{l}\text { Left frontoparietal } \\
\text { region, right } \\
\text { occipital }\end{array}$ & $\begin{array}{c}\text { Actinomyces } \\
\text { meyeri, } \\
\text { Aggregatibacter } \\
\text { actinomycetem- } \\
\text { comitans }\end{array}$ & $\begin{array}{l}\text { Drainage of } \\
\text { the lesions }\end{array}$ & Amoxicillin & 12 & Good \\
\hline $\begin{array}{c}\text { Chacko \& } \\
\text { Chandy [27] }\end{array}$ & 1997 & $60 / \mathrm{M}$ & drowsy, confusion & 6 & $\begin{array}{l}\text { Right frontal (1), } \\
\text { left and right } \\
\text { parietal lobes (5) }\end{array}$ & - & $\begin{array}{l}\text { Drainage of } \\
\text { the lesions }\end{array}$ & $\begin{array}{c}\text { Penicillin, } \\
\text { chloramphenicol, } \\
\text { metronidazole, } \\
\text { ampicillin, } \\
\text { trimethoprim- } \\
\text { sulfamethoxazole }\end{array}$ & 4 & Good \\
\hline $\begin{array}{l}\text { Stepanović } \\
\text { et al. [38] }\end{array}$ & 2005 & $47 / \mathrm{M}$ & $\begin{array}{c}\text { headache, nausea, } \\
\text { vomiting, } \\
\text { progressive left } \\
\text { hemiparesis }\end{array}$ & 3 & Right occipital (3) & $\begin{array}{c}\text { Aggregatibacter } \\
\text { actinomycetem- } \\
\text { comitans }\end{array}$ & $\begin{array}{l}\text { Drainage of } \\
\text { the lesions }\end{array}$ & $\begin{array}{c}\text { Ceftriaxone, } \\
\text { amikacin, } \\
\text { metronidazole }\end{array}$ & 1 & Good \\
\hline $\begin{array}{c}\text { Ewald et al. } \\
\text { [29] }\end{array}$ & 2006 & $49 / \mathrm{M}$ & $\begin{array}{l}\text { right arm paresis, } \\
\text { left leg paresis, } \\
\text { seizures }\end{array}$ & more than 2 & - & $\begin{array}{l}\text { Fusobacterium } \\
\text { nucleatum }\end{array}$ & $\begin{array}{l}\text { Drainage of } \\
\text { the lesions }\end{array}$ & $\begin{array}{c}\text { Clindamycin, } \\
\text { metronidazole, } \\
\text { cefuroxim }\end{array}$ & 12 & Good \\
\hline $\begin{array}{l}\text { Rahamat- } \\
\text { Langendoen } \\
\text { et al. [36] }\end{array}$ & 2011 & $42 / \mathrm{M}$ & $\begin{array}{l}\text { confusion and } \\
\text { reduced } \\
\text { consciousness }\end{array}$ & 3 & $\begin{array}{l}\text { Right parietal (2), } \\
\text { left frontal (1) }\end{array}$ & $\begin{array}{c}\text { Aggregatibacter } \\
\text { actinomycetem- } \\
\text { comitans }\end{array}$ & $\begin{array}{l}\text { Drainage of } \\
\text { the lesions }\end{array}$ & $\begin{array}{l}\text { Antibiotic } \\
\text { treatment }\end{array}$ & 12 & Good \\
\hline $\begin{array}{c}\text { Azenha et al. } \\
\text { [26] }\end{array}$ & 2012 & $70 / \mathrm{M}$ & $\begin{array}{c}\text { headache, } \\
\text { dizziness, nausea, } \\
\text { mild fever, left } \\
\text { hemiparesis }\end{array}$ & 3 & $\begin{array}{l}\text { Left frontal, right } \\
\text { occipital, left } \\
\text { thalamic }\end{array}$ & $\begin{array}{c}\text { Streptococcus } \\
\text { viridians, } \\
\text { Bacteroides }\end{array}$ & $\begin{array}{l}\text { Drainage of } \\
\text { the lesions }\end{array}$ & $\begin{array}{c}\text { Ceftriaxone, } \\
\text { amoxicillin, } \\
\text { metronidazole }\end{array}$ & 12 & Good \\
\hline
\end{tabular}


Table 2. Cont

\begin{tabular}{|c|c|c|c|c|c|c|c|c|c|c|}
\hline Authors & Year & Age/Sex & $\begin{array}{l}\text { Neurological } \\
\text { Clinical } \\
\text { Presentation }\end{array}$ & $\mathbf{N}^{\circ}$ of BAs & BAs Location & Pathogens & $\begin{array}{l}\text { Surgical } \\
\text { Treatment }\end{array}$ & $\begin{array}{c}\text { Medical } \\
\text { Treatment }\end{array}$ & $\begin{array}{c}\text { Follow-Up } \\
\text { (Months) }\end{array}$ & Outcome \\
\hline $\begin{array}{l}\text { Clifton et al. } \\
\text { [28] }\end{array}$ & 2012 & $56 / \mathrm{M}$ & nausea, vomiting & 2 & $\begin{array}{l}\text { Right frontal, left } \\
\text { frontal }\end{array}$ & - & $\begin{array}{l}\text { Drainage of } \\
\text { the lesions } \\
\text { and dental } \\
\text { extraction }\end{array}$ & $\begin{array}{l}\text { Vancomycin, } \\
\text { aciclovir, } \\
\text { ceftriaxone }\end{array}$ & 3 & Good \\
\hline Wu et al. [40] & 2014 & $32 / \mathrm{M}$ & $\begin{array}{l}\text { left arm paresis, } \\
\text { left facial palsy }\end{array}$ & 3 & $\begin{array}{l}\text { Right frontal, } \\
\text { right temporal, } \\
\text { right basal ganglia }\end{array}$ & $\begin{array}{c}\text { Prevotella } \\
\text { denticola }\end{array}$ & $\begin{array}{l}\text { Drainage of } \\
\text { the lesions }\end{array}$ & $\begin{array}{c}\text { Cefepime, } \\
\text { penicillin, } \\
\text { metronidazole }\end{array}$ & 6 & Good \\
\hline $\begin{array}{l}\text { Pallesen et al. } \\
\text { [35] }\end{array}$ & 2014 & $55 / \mathrm{M}$ & left leg paresis & 3 & $\begin{array}{l}\text { Right frontal, } \\
\text { right occipital, left } \\
\text { occipital }\end{array}$ & $\begin{array}{c}\text { Streptococcus } \\
\text { intermedius, } \\
\text { Staphylococcus } \\
\text { warneri }\end{array}$ & $\begin{array}{c}\text { Drainage of } \\
\text { the lesions }\end{array}$ & $\begin{array}{l}\text { Ceftriaxone, } \\
\text { vancomycin }\end{array}$ & 6 & $\begin{array}{l}\text { Left leg } \\
\text { paresis }\end{array}$ \\
\hline $\begin{array}{c}\text { Martiny et al. } \\
{[34]}\end{array}$ & 2017 & $66 / \mathrm{M}$ & $\begin{array}{c}\text { dysarthria, } \\
\text { diplopia, } \\
\text { nystagmus, right } \\
\text { peripheral facial } \\
\text { palsy, right } \\
\text { deafness }\end{array}$ & 3 & $\begin{array}{c}\text { Right } \\
\text { cerebellopontine } \\
\text { angle, cerebellum }\end{array}$ & $\begin{array}{l}\text { Campylobacter } \\
\text { rectus }\end{array}$ & $\begin{array}{l}\text { Drainage of } \\
\text { the lesions } \\
\text { and dental } \\
\text { extraction }\end{array}$ & $\begin{array}{l}\text { Meropenem, } \\
\text { doxycycline }\end{array}$ & 10 & Good \\
\hline $\begin{array}{c}\text { AlHarmi et al. } \\
{[6]}\end{array}$ & 2018 & $8 / \mathrm{F}$ & $\begin{array}{c}\text { fever, left } \\
\text { hemiparesis, } \\
\text { hyporeflexia }\end{array}$ & 5 & $\begin{array}{l}\text { Right frontal (3), } \\
\text { left parietal (2) }\end{array}$ & - & $\begin{array}{c}\text { Drainage of } \\
\text { the lesions }\end{array}$ & $\begin{array}{l}\text { Meropenem, } \\
\text { vancomycin }\end{array}$ & 1 & $\begin{array}{l}\text { Left hemi- } \\
\text { paresis }\end{array}$ \\
\hline $\begin{array}{l}\text { Viviano \& } \\
\text { Cocca [39] }\end{array}$ & 2018 & $28 / \mathrm{M}$ & $\begin{array}{l}\text { headache, nuchal } \\
\text { pain, vomiting, } \\
\text { confusion }\end{array}$ & 2 & $\begin{array}{l}\text { Left parietal, left } \\
\text { occipital }\end{array}$ & $\begin{array}{l}\text { Streptococcus } \\
\text { intermedius, } \\
\text { Actinomyces }\end{array}$ & $\begin{array}{l}\text { Drainage of } \\
\text { the lesions }\end{array}$ & $\begin{array}{l}\text { Vancomycin, } \\
\text { ceftriaxone, } \\
\text { metronidazole, } \\
\text { clindamycin, } \\
\text { ampicillin }\end{array}$ & 6 & Good \\
\hline Ryan et al. [37] & 2019 & $79 / \mathrm{M}$ & $\begin{array}{l}\text { progressive right } \\
\text { arm paresis }\end{array}$ & 2 & $\begin{array}{c}\text { Left parietal, right } \\
\text { frontal }\end{array}$ & $\begin{array}{l}\text { Blastomyces } \\
\text { dermatitidis }\end{array}$ & $\begin{array}{l}\text { Drainage of } \\
\text { the lesions } \\
\text { and dental } \\
\text { extraction }\end{array}$ & $\begin{array}{l}\text { Vancomycin, } \\
\text { ceftriaxone, } \\
\text { metronidazole }\end{array}$ & 6 & Good \\
\hline
\end{tabular}


Table 2. Cont

\begin{tabular}{|c|c|c|c|c|c|c|c|c|c|c|}
\hline Authors & Year & Age/Sex & $\begin{array}{l}\text { Neurological } \\
\text { Clinical } \\
\text { Presentation }\end{array}$ & $\mathbf{N}^{\circ}$ of BAs & BAs Location & Pathogens & $\begin{array}{l}\text { Surgical } \\
\text { Treatment }\end{array}$ & $\begin{array}{c}\text { Medical } \\
\text { Treatment }\end{array}$ & $\begin{array}{l}\text { Follow-Up } \\
\text { (Months) }\end{array}$ & Outcome \\
\hline Jung et al. [31] & 2019 & $45 / \mathrm{M}$ & $\begin{array}{c}\text { right facial } \\
\text { spasms, tingling } \\
\text { of the right arm, } \\
\text { paresthesia, } \\
\text { dysarthria }\end{array}$ & 3 & $\begin{array}{c}\text { Right frontal (2), } \\
\text { left frontal (1) }\end{array}$ & $\begin{array}{l}\text { Streptococcus } \\
\text { anginosus }\end{array}$ & $\begin{array}{l}\text { Drainage of } \\
\text { the lesions } \\
\text { and dental } \\
\text { extraction }\end{array}$ & $\begin{array}{c}\text { Metronidazole, } \\
\text { cefotaxime, } \\
\text { ceftriaxone, } \\
\text { Vancomycin, } \\
\text { Augmentin }\end{array}$ & 3 & Good \\
\hline $\begin{array}{c}\text { Gemelli et al. } \\
\text { [30] }\end{array}$ & 2020 & $71 / \mathrm{F}$ & $\begin{array}{l}\text { confusion, } \\
\text { disorientation in } \\
\text { time and space } \\
\text { with inattention }\end{array}$ & more than 10 & $\begin{array}{c}\text { Frontal and } \\
\text { parietal lobes }\end{array}$ & $\begin{array}{l}\text { Aggregatibacter } \\
\text { aphrophilus }\end{array}$ & $\begin{array}{c}\text { Dental } \\
\text { extractions }\end{array}$ & $\begin{array}{l}\text { Vancomycin, } \\
\text { piperacillin/tazobactam, } \\
\text { ceftriaxone }\end{array}$ & m, 2 & Good \\
\hline
\end{tabular}

BAs, brain abscesses; F, female; $\mathrm{M}$, male. 


\subsection{Demographic, Clinical and Radiological Characteristics}

Overall, the median age of patients was 48.6 years (range 8-79) and the proportion of male patients was $87.5 \%$. Only two patients were female. In most of the cases (75\%) multiple BAs were the result of periodontal disease or multiple dental caries. Multiple BAs followed professional tooth cleaning in two cases $[35,39]$ and dental extraction in one case [40]. The most common clinical neurological presentations were the onset of a motor deficit (62.5\%) and confusion and reduced consciousness (37.5\%). Headache and nausea were present in $18.8 \%$ of cases. One patient reported seizures [29]. The median overall number of BAs was 3.7 and the most common locations were the frontal $(46.7 \%)$, parietal (30\%), and occipital (13.3\%) lobes, whereas cerebellum (5\%), basal ganglia (3.3\%) and temporal lobe $(1.7 \%)$ were rare locations. The right hemisphere was more involved $(63.3 \%)$ than the left hemisphere (36.7\%). In all cases, BAs appeared as well-defined, ovalshaped and hypoechoic lesions, which were isointense to the muscle on T1 images and hyperintense on T2 images on magnetic resonance imaging (MRI). Post-contrast lesions showed homogeneous enhancement in all of cases.

\subsection{Pathogens, Treatment and Clinical Outcome}

The most common pathogens involved in the development of multiple BAs were Streptococcus viridans (with its different species), that was identified in $31.3 \%$ of cases, and Aggregatibacter actinomycetemcomitans (18.8\% of cases). Other pathogens identified in single cases were Campylobacter rectus, Fusobacterium nucleatum, Prevotella denticola, Staphylococcus warneri, Actinomyces meyeri and Blastomyces dermatitidis, present in $50 \%$ of Gram-positive bacteria and 50\% of Gram-negative bacteria.

A total of 14 out of 16 patients (87.5\%) underwent craniotomy and surgical drainage of at least one of the multiple BAs in concomitance with antibiotic therapy, whereas five of these patients also underwent dental extractions (31.3\%). One patient [30] underwent dental extractions and antibiotic therapy without surgical drainage of BAs and one patient [33] died without any surgical cranial or oral treatment.

The most common antibiotics used were cephalosporins ( $66.7 \%$ of cases), metronidazole $(53.3 \%)$, vancomycin $(46.7 \%)$ and penicillin $(46.7 \%)$. Median follow-up was 6 months. A total of 13 patients $(81.3 \%)$ had a good outcome, whereas two patients $(12.5 \%)$ showed persistent deficits in motor skills (paresis) at last follow-up. One patient died during hospitalization; therefore, overall mortality and morbidity of multiple BAs was $6.3 \%$ and $12.5 \%$, respectively.

\section{Discussion}

\subsection{History and Epidemiology}

Sir Percival Pott was probably the first to recognize and document that infections elsewhere in the body could spread and cause a BA [41,42]. Then, the French surgeon Morand, in 1768, made the first report of successful surgical treatment of an otitic BA with good recovery [43]. In 1891, Topuzlu treated surgically, for the first time, a BA that originated as a complication of a depression fracture of the cranial inner table, using contemporary anesthesiological and surgical techniques [44,45]. It has been postulated that oral microorganisms may enter the cranium by direct extension (hematogenous spread, local lymphatics) or indirectly by extraoral odontogenic infection [46]. Hematogenous spreading can occur through general circulation or along the facial, angular, ophthalmic or other veins which lack valves, through the cavernous sinus and into the cranium $[35,47]$. Pallesen et al. [35] described both modes of infection dissemination, either by means of direct extension via fascial planes or by means of hematogenic or lymphatic spread. Immunodeficiency due to HIV infection, alcohol abuse, diabetes, chemotherapy or cancer may promote the development of BAs [48-50].

Oral infections are a rare cause of BAs, contrary to general belief and, in most cases, dental radiography does not help to make a proper diagnosis; it is difficult to accurately diagnose odontogenic disease due to its occurrence as an acute inflammatory progression 
of the soft tissue around the alveolar bone [31]. In support of a medical diagnosis, recent papers reported the role of prognostic early markers in the diagnosis of oral diseases [21-23]. Patients with periodontitis presented significantly higher serum and salivary Galectin-3 levels in comparison to healthy subjects, suggesting that periodontitis and Endothelin-1 were the significant predictors of serum and salivary Galectin-3 levels, respectively [21]. With a suspected BA, further diagnostic imaging studies, such as, at first, a head computed tomography (CT) scan, should be taken into account [51-53]. In BAs with a suspected remote infection, it is reasonable to carefully evaluate the head and neck areas close to the brain and chronic infectious diseases such as odontogenic infection that can cause such pathology [1,31,54]. A total of $40 \%$ of BAs are caused by chronic otitis media or mastoiditis, $10 \%$ by maxillary sinusitis or paranasal sinusitis, and $50 \%$ through the spread of cardiac or pulmonary infections [31]. In a few cases (5-7\%), BAs can have an odontogenic origin that can occur after dental extraction, but also after professional tooth cleaning, mostly in patients with poor oral health, as we reported. Bacteremia's occurring even as a result of routine daily dental interventions such as toothbrushing has been well documented, although its significance remains unclear $[55,56]$. Although diet and the environment have a great impact on gut microbiota [57], they exert minimal effect on the composition of oral bacteria and oral microbiota. However, because of ecological interactions and environmental conditions, over time, the oral anaerobes eventually become the predominant group in the endodontic and periapical infections [58,59]. Anaerobic infections (bacilli and Gram-positive cocci) are associated with incidence of acute signs and symptoms, such as pain, sensitivity to pressure and cellulitis and are characterized by abscess formation, foul-smelling pus and tissue destruction [58]. Some previous studies highlighted the role of the oral microbiota in the colonization of dental implants [60,61]. Through bacterial cultures, it has been seen that the quality of microorganisms present in the oral cavity before the surgical implants determines what will subsequently populate the implant itself. Furthermore, it has been shown that the biofilm present in peri-implantitis has a composition similar to that of periodontitis, with high levels of periodontal pathogens, increasing the risk of peri-implantitis in patients with a past history of periodontitis and increasing the potential risk of hematogenous dissemination and BAs [60,62].

\subsection{Pathogen Features and Clinical Presentation}

Most dental abscesses are caused by the resident oral microbiota that enters normally sterile tissues. The major isolates are streptococci and anaerobic bacteria, which are regarded as normal flora of the tooth and gingival crevice [63]. The microbiota specificity in odontogenic infections has been more clearly delineated with technological advances in sampling and anaerobic culture. Li et al. [46] reported that the most frequent species isolated in BAs are Gram-positive cocci (Streptococcus mutans, Streptococcus milha, Streptococcus intennedius) and Gram-negative rods (Aggregatibacter actinomycetemcomitans, Prevotella oralis and Fusobacterium nucleatum). Laulajainen-Hongisto [64] reported that the most common pathogens involved in intracranial BAs were Streptococcus (42\%), Fusobacteriae (14\%), Aggregatibacter actinomycetemcomitans (8\%) and Staphylococcus spp $(8 \%)$. Similarly, we reported that the most common pathogens involved in the development of multiple BAs were Streptococcus viridans (with its different species), which was identified in $31.3 \%$ of cases, and Aggregatibacter actinomycetemcomitans (18.8\% of cases), although Gram-positive and Gram-negative bacteria seem to be involved in equal part, as we found in this review. Anaerobic infection is favored in the brain due to the low oxygen tension of the interstitium and because the BA causes focal infarcts due to decreased oxygen supply [46]. Streptococcus intermedius, which is a member of the Streptococcus anginosus group, despite being a part of the normal microbiota, is one of the most common pathogens associated with brain and liver abscesses and thoracic empyema, increasing, as a result, the morbidity and mortality rates in affected patients [65]. Some oral bacteria such as Aggregatibacter actinomycetemcomitans is non-motile, facultative anaerobic, small Gram-negative coccobacillus that shows a predilection for the central nervous system when 
they produce systemic disease $[46,66]$. However, it is difficult to isolate through culture due to its fastidious slow-growing nature, especially because it is often part of mixed infection with other bacteria $[36,67,68]$. As our review confirmed, BAs were often caused by poly-microorganisms (in $25 \%$ of cases) and for this reason it is difficult to identify accurate pathogens [31].

In the case of a single BA, the presenting features and clinical neurological presentations depend on the size and intracranial location of BA, the virulence of the infecting agents, the immunologic status of the host, and the cerebral edema caused by the expanding intracranial mass lesion [28]. The classic triad of fever, headache and focal neurologic deficit is present in less than $50 \%$ of cases [28]. In the case of multiple BAs, the classic triad of fever, headache and focal neurologic deficit is present in more than $63 \%$ of cases. Similarly, mental status change and reduced consciousness is present in up to $37.5 \%$ of patients, as we reported, often accompanied by the acute onset of meningeal signs, suggesting either herniation or intraventricular rupture of the abscess.

\subsection{Differential Diagnosis and Outcome}

In addition to a clinical examination, diagnostic imaging should be used to diagnose BAs. The diagnosis of BAs is sustained by contrast-enhanced MRI, where the abscesses appear as typical ring-like structures surrounded by edema. Differential diagnosis between BA and tumor is of extreme importance, infection being differentiated from neoplastic disease by virtue of hyperintense signals in diffusion-weighted MRI scans [35]. Management of multiple BAs typically involves surgical drainage of at least one of the BAs and simultaneous eradication of the primary odontogenic source of sepsis in association with intravenous administration of high doses of antibiotic agents [28,31,34,37].

Antibiotics are often changed (100\% of cases) during the entire hospitalization for multiple BAs in order to find the most appropriate treatment. When antimicrobial sensitivity patterns are determined, treatment is then tailored based on the result. In patients with multiple small BAs who are neurologically intact, the disease is managed medically, with close serial monitoring performed using neuroimaging to determine the response to antibiotic therapy [33]. Otherwise, patients with neurological deficits may require urgent evacuation of the lesion $[36,69]$. For single BA, the proportion of patients with good outcomes enabling return to prior occupation rose over time, from $12 \%$ in $1970-1989$ to $24 \%$ in 1990-2012 [48]. Patients with multiple BAs experienced a good recovery $(81.3 \%)$ with a morbidity rate of $12.5 \%$.

There is no definite rule for the treatment of BA. Antibiotics are considered to be the first line of treatment and should be started immediately. It has been reported that the Streptococcus anginosus group is sensitive to penicillin, ampicillin, cephalosporin, clindamycin and erythromycin, and that Aaggregatibacter actinomycetemcomitans [31] is sensitive to strong synergistic effects with metronidazole in combination with amoxicilline [70]. Medical treatment alone is not recommended for pyogenic BAs greater than $2.5-3 \mathrm{~cm}$ in diameter and for refractory smaller BAs $[6,58]$. Surgical options include open craniotomy with complete excision and stereotactic aspiration. Open surgery is indicated for large and multiple lesions, cerebellar lesions which obstruct CSF flow and fungal abscesses, and contraindicated in deep-seated lesions [6]. Aspiration is associated with reduced morbidity; however, up to $70 \%$ of patients require a repeated procedure due to factors such as incomplete aspiration and inadequate antibiotic coverage [6,58]. When multiple abscesses are present, a successful strategy dictates aspiration of lesions $>2.5 \mathrm{~cm}$ and treating other lesions conservatively for $6-8$ weeks [6].

Oral pathogens are necessary, but not sufficient for odontogenic BAs. The role of microbiota is strictly connected with the immune system that appears to be the crucial determinant of disease susceptibility and severity $[46,58]$. Cardiovascular disease, chronic obstructive respiratory disease, rheumatic disease, diabetes, chronic inflammatory bowel diseases, cancer and organ transplants are factors that affect patients rendering medically immunocompromised and the oral microbiota $[46,71-76]$. BA can result in permanent 
neurological sequelae such as epilepsy, cranial nerve palsies, intellectual and behavioral disorders, motor deficits, hydrocephalus and death. Early diagnosis and intervention can lead to reduced mortality rates and improved outcomes [6,77]. Poor prognosis is reported in immunocompromised patients, children younger than 1 year of age, in delayed diagnosis, in the case of coma or severe mental status change at the time of diagnosis and when BAs rupture into ventricles [6,78-82]. Prevention of abscesses by routine dental and oral hygiene care or early removal of abscessed or non-treatable teeth is prudent and appears to be more important in the immunocompromised patient.

Our review has several limitations. The reported cases are retrospective and only single case reports. Second, our review might be underpowered because this topic is seldom reported in the literature and subjected to continuous updating. Lastly, the role of oral microbiota in the onset of multiple BAs is still under investigation. For this reason, larger studies are required to analyze the relationship between multiple BAs and oral microbiota.

\section{Conclusions}

Dental infection is an uncommon source of multiple BAs, often but not always seen in immunocompromised patients. Streptococcus viridans and Aggregatibacter actinomycetemcomitans seem to be the most common pathogens involved in the development of multiple BAs, but at the same time bacteremia (depending upon several factors such as local oral inflammation, oral microbiota and systemic disease) play an important role in their development. A detailed history taking and physical examination, as well as early detection of the lesion with prompt medical and surgical treatments, can lead to an early diagnosis and a successful management of multiple BAs, reducing the duration of empirical antibiotic therapy and the time of hospitalization. Serum and salivary Galectin-3 levels were demonstrated to be a valuable prognostic early marker of periodontitis. A multidisciplinary approach is essential in the management of multiple BAs. Further studies are required to better understand the role of microbiota in the development of multiple BAs.

Author Contributions: Conceptualization, N.M., B.R. and P.P.; methodology, N.M. and B.R.; data collection, N.M. and B.R.; formal analysis, N.M. and B.R.; writing-original draft preparation, N.M., P.P. and B.R.; investigation, N.M., B.R. and B.C.; resources, B.R.; data curation, N.M, B.R. and W.M.; writing-review and editing, N.M., B.R., P.P., M.C. and A.S. All authors have read and agreed to the published version of the manuscript.

Funding: This research received no external funding.

Institutional Review Board Statement: Not applicable.

Informed Consent Statement: Not applicable.

Data Availability Statement: Data sharing not applicable.

Acknowledgments: We thank Federica Tataranni for her English revision.

Conflicts of Interest: The authors declare no conflict of interest.

\section{References}

1. Kichenbrand, C.; Marchal, A.; Mouraret, A.; Hasnaoui, N.; Guillet, J.; Rech, F.; Phulpin, B. Brain abscesses and intracranial empyema due to dental pathogens: Case series. Int. J. Surg. Case Rep. 2020, 69, 35-38. [CrossRef]

2. Alvis Miranda, H.; Castellar-Leones, S.M.; Elzain, M.A.; Moscote-Salazar, L.R. Brain abscess: Current management. J. Neurosci. Rural Pract. 2013, 4 (Suppl. 1), S67-S81.

3. Mathisen, G.E.; Johnson, J.P. Brain abscess. Clin. Infect. Dis. 1997, 25, 763-779. [CrossRef]

4. Menon, S.; Bharadwaj, R.; Chowdhary, A.; Kaundinya, D.V.; Palande, D.A. Current epidemiology of intracranial abscesses: A prospective 5 year study. J. Med. Microbiol. 2008, 57, 1259-1268. [CrossRef]

5. Olsen, I. Update on bacteraemia related to dental procedures. Transfus. Apher. Sci. 2008, 39, 173-178. [CrossRef] [PubMed]

6. AlHarmi, R.A.; Henari, D.F.; Jadah, R.H.S.; AlKhayyat, H.M. A brain populated with space-occupying lesions: Identifying the culprit. BMJ Case Rep. 2018, 24. [CrossRef] [PubMed]

7. Hollin, S.A.; Hayashi, H.; Gross, S.W. Intracranial abscesses of odontogenic origin. Oral Surg. Oral Med. Oral Pathol. 1967, 23, 277-293. [CrossRef] 
8. MacEwan, W. Pyogenic Infective Diseases of the Brain and Spinal Cord; Maclehose Press: Glasgow, UK, 1893.

9. Sulyanto, R.M.; Thompson, Z.A.; Beall, C.J.; Leys, E.J.; Griffen, A.L. The Predominant Oral Microbiota Is Acquired Early in an Organized Pattern. Sci. Rep. 2019, 22, 10550. [CrossRef] [PubMed]

10. Liébana-Ureña, J.; González, M.P.; Liébana, M.J.; Parra, L. Composición y ecología de la microbiota oral. In Microbiología Oral; Liébana-Ureña, J., Ed.; McGraw-Hill: Madrid, Spain, 2002; pp. 514-525.

11. Dewhirst, F.E. The oral microbiome: Critical for understanding oral health and disease. J. Calif. Dent. Assoc. 2016, 44, 409-410. [PubMed]

12. Costalonga, M.; Herzberg, M.C. The oral microbiome and the immunobiologyof periodontal disease and caries. Immunol. Lett. 2014, 162, 22-38. [CrossRef]

13. Kumar, P.S. From focal sepsis to periodontal medicine: A century of exploringthe role of the oral microbiome in systemic disease. J. Physiol. 2017, 595, 465-476. [CrossRef]

14. Sami, A.; Elimairi, I.; Stanton, C.; Ross, R.P.; Ryan, C.A. The Role of the Microbiome in Oral Squamous Cell Carcinoma with Insight into the Microbiome-Treatment Axis. Int. J. Mol. Sci. 2020, 21, 8061.

15. Montemurro, N.; Perrini, P.; Rapone, B. Clinical Risk and Overall Survival in Patients with Diabetes Mellitus, Hyperglycemia and Glioblastoma Multiforme. A Review of the Current Literature. Int. J. Environ. Res. Public Health 2020, 17, 8501. [CrossRef]

16. Wang, L.; Ganly, I. The oral microbiome and oral cancer. Clin. Lab. Med. 2014, 34, 711-719. [CrossRef]

17. Graves, D.T.; Correa, J.D.; Silva, T.A. The oral microbiota is modified by systemic diseases. J. Dent. Res. 2019, 98, 148-156. [CrossRef]

18. Chen, B.; Zhao, Y.; Li, S.; Yang, L.; Wang, H.; Wang, T.; Bin, S.; Gai, Z.; Heng, X.; Zhang, C.; et al. Variations in oral microbiome profiles in rheumatoid arthritis and osteoarthritis with potential biomarkers for arthritis screening. Sci. Rep. 2018, $20,17126$. [CrossRef]

19. Cobb, C.M.; Kelly, P.J.; Williams, K.B.; Babbar, S.; Angolkar, M.; Derman, R.J. The oral microbiome and adverse pregnancy outcomes. Int. J. Women Health 2017, 9, 551-559. [CrossRef] [PubMed]

20. Montemurro, N. Glioblastoma Multiforme and Genetic Mutations: The Issue Is Not Over Yet. An Overview of the Current Literature. J. Neurol. Surg. A Cent. Eur. Neurosurg. 2020, 81, 64-70. [CrossRef] [PubMed]

21. Isola, G.; Polizzi, A.; Alibrandi, A.; Williams, R.C.; Lo Giudice, A. Analysis of galectin-3 levels as a source of coronary heart disease risk during periodontitis. J. Periodontal Res. 2021, 28-32. [CrossRef]

22. Isola, G.; Polizzi, A.; Patini, R.; Ferlito, S.; Alibrandi, A.; Palazzo, G. Association among serum and salivary A. actinomycetemcomitans specific immunoglobulin antibodies and periodontitis. BMC Oral Health 2020, 20, 283. [CrossRef] [PubMed]

23. Eickholz, P.; Schröder, M.; Asendorf, A.; Schacher, B.; Oremek, G.M.; Kaiser, F.; Wohlfeil, M.; Nibali, L. Effect of nonsurgical periodontal therapy on haematological parameters in grades B and C periodontitis: An exploratory analysis. Clin. Oral Investig. 2020, 24, 4291-4299. [CrossRef]

24. Kebschull, M.; Papapanou, P.N. Periodontal microbial complexes associated with specific cell and tissue responses. J. Clin. Periodontol. 2011, 11, 17-27. [CrossRef] [PubMed]

25. Moher, D.; Shamseer, L.; Clarke, M.; Ghersi, D.; Liberati, A.; Petticrew, M.; Shekelle, P.; Stewart, L.A.; PRISMA-P Group. Preferred reporting items for systematic review and meta-analysis protocols (PRISMA-P) 2015 statement. Syst. Rev. 2015, 4, 1. [CrossRef] [PubMed]

26. Azenha, M.R.; Homsi, G.; Garcia, I.R., Jr. Multiple brain abscess from dental origin: Case report and literature review. Oral Maxillofac. Surg. 2012, 16, 393-397. [CrossRef] [PubMed]

27. Chacko, A.G.; Chandy, M.J. Diagnostic and staged stereotactic aspiration of multiple bihemispheric pyogenic brain abscesses. Surg. Neurol. 1997, 48, 278-282. [CrossRef]

28. Clifton, T.C.; Kalamchi, S. A case of odontogenic brain abscess arising from covert dental sepsis. Ann. R. Coll. Surg. Engl. 2012, 94, e41-e43. [CrossRef]

29. Ewald, C.; Kuhn, S.; Kalff, R. Pyogenic infections of the central nervous system secondary to dental affections-A report of six cases. Neurosurg. Rev. 2006, 29, 163-166. [CrossRef] [PubMed]

30. Gemelli, N.A.; Boccalatte, L.A.; Ciarrocchi, N.M. Multiple Brain Abscesses Due to Odontogenic Infection. Neurocrit. Care. 2020, 33, 604-606. [CrossRef] [PubMed]

31. Jung, K.H.; Ro, S.S.; Lee, S.W.; Jeon, J.Y.; Park, C.J.; Hwang, K.G. Multiple brain abscesses treated by extraction of the maxillary molars with chronic apical lesion to remove the source of infection. Maxillofac. Plast. Reconstr. Surg. 2019, 41, 25. [CrossRef] [PubMed]

32. Kuijper, E.J.; Wiggerts, H.O.; Jonker, G.J.; Schaal, K.P.; de Gans, J. Disseminated actinomycosis due to Actinomyces meyeri and Actinobacillus actinomycetemcomitans. Scand. J. Infect. Dis. 1992, 24, 667-672. [CrossRef]

33. Marks, P.V.; Patel, K.S.; Mee, E.W. Multiple brain abscesses secondary to dental caries and severe periodontal disease. Br. J. Oral Maxillofac. Surg. 1988, 26, 244-247. [CrossRef]

34. Martiny, D.; Dauby, N.; Konopnicki, D.; Kampouridis, S.; Jissendi Tchofo, P.; Horoi, M.; Vlaes, L.; Retore, P.; Hallin, M.; Vandenberg, O. MALDI-TOF MS contribution to the diagnosis of Campylobacter rectus multiple skull base and brain abscesses. New Microbes New Infect. 2017, 19, 83-86. [CrossRef] [PubMed] 
35. Pallesen, L.P.; Schaefer, J.; Reuner, U.; Leonhardt, H.; Engellandt, K.; Schneider, H.; Reichmann, H.; Puetz, V. Multiple brain abscesses in an immunocompetent patient after undergoing professional tooth cleaning. J. Am. Dent. Assoc. 2014, 145, 564-568. [CrossRef] [PubMed]

36. Rahamat-Langendoen, J.C.; van Vonderen, M.G.; Engström, L.J.; Manson, W.L.; van Winkelhoff, A.J.; Mooi-Kokenberg, E.A. Brain abscess associated with Aggregatibacter actinomycetemcomitans: Case report and review of literature. J. Clin. Periodontol. 2011, 38, 702-706. [CrossRef] [PubMed]

37. Ryan, D.; Lippert, W.C.; Fenwick, A.J.; Bhatt, M.; Jones, C.R. Central Nervous System Blastomycosis With Multiple Brain Abscesses Presenting as Right Upper Extremity Weakness. Neurohospitalist 2019, 9, 230-234. [CrossRef]

38. Stepanović, S.; Tosić, T.; Savić, B.; Jovanović, M.; K'ouas, G.; Carlier, J.P. Brain abscess due to Actinobacillus actinomycetemcomitans. APMIS 2005, 113, 225-228. [CrossRef]

39. Viviano, M.; Cocca, S. Multiple brain abscesses after professional tooth cleaning: Case report and literature review. J. Stomatol. Oral Maxillofac. Surg. 2018, 119, 432-435. [CrossRef]

40. Wu, P.C.; Tu, M.S.; Lin, P.H.; Chen, Y.S.; Tsai, H.C. Prevotella brain abscesses and stroke following dental extraction in a young patient: A case report and review of the literature. Intern. Med. 2014, 53, 1881-1887. [CrossRef] [PubMed]

41. Nathoo, N.; Nadvi, S.S.; Narotam, P.K.; van Dellen, J.R. Brain abscess: Management and outcome analysis of a computed tomography era experience with 973 patients. World Neurosurg. 2011, 75, 716-726. [CrossRef] [PubMed]

42. Muzumdar, D.; Jhawar, S.; Goel, A. Brain abscess: An overview. Int. J. Surg. 2011, 9, 136-144. [CrossRef]

43. Nathoo, N.; Narotam, P.K.; Nadvi, S.; van Dellen, J.R. Taming an old enemy: A profile of intracranial suppuration. World Neurosurg. 2012, 77, 484-490. [CrossRef]

44. Perrini, P.; Montemurro, N.; Iannelli, A. The contribution of Carlo Giacomini (1840-1898): The limbus Giacomini and beyond. Neurosurgery 2013, 72, 475-482. [CrossRef] [PubMed]

45. Mut, M.; Dinç, G.; Naderi, S. On the report of the first successful surgical treatment of brain abscess in the Ottoman Empire by Dr. Cemil Topuzlu in 1891. Neurosurgery 2007, 61, 869-872. [CrossRef] [PubMed]

46. Li, X.; Tronstad, L.; Olsen, I. Brain abscesses caused by oral infection. Endod. Dent. Traumatol. 1999, 15, 95-101. [CrossRef]

47. Montemurro, N.; Anania, Y.; Cagnazzo, F.; Perrini, P. Survival outcomes in patients with recurrent glioblastoma treated with Laser Interstitial Thermal Therapy (LITT): A systematic review. Clin. Neurol. Neurosurg. 2020, 195, 105942. [CrossRef]

48. Laulajainen-Hongisto, A.; Lempinen, L.; Färkkilä, E.; Saat, R.; Markkola, A.; Leskinen, K.; Blomstedt, G.; Aarnisalo, A.A.; Jero, J. Intracranial abscesses over the last four decades; changes in aetiology, diagnostics, treatment and outcome. Infect. Dis. 2016, 48, 310-316. [CrossRef]

49. Erdogan, E.; Cansever, T. Pyogenic brain abscess. Neurosurg. Focus 2008, 24, E2. [CrossRef]

50. Perrini, P.; Montemurro, N.; Caniglia, M.; Lazzarotti, G.; Benedetto, N. Wrapping of intracranial aneurysms: Single-center series and systematic review of the literature. Br. J. Neurosurg. 2015, 29, 785-791. [CrossRef] [PubMed]

51. Montemurro, N.; Perrini, P. Will COVID-19 change neurosurgical clinical practice? Br. J. Neurosurg. 2020, 1, 1-2. [CrossRef]

52. Montemurro, N. Intracranial hemorrhage and COVID-19, but please do not forget "old diseases" and elective surgery. Brain Behav. Immun. 2021, 92, 207-208. [CrossRef] [PubMed]

53. Montemurro, N.; Perrini, P.; Mangini, V.; Galli, M.; Papini, A. The Y-shaped trabecular bone structure in the odontoid process of the axis: A CT scan study in 54 healthy subjects and biomechanical considerations. J. Neurosurg. Spine. 2019, 1, 1-8. [CrossRef]

54. Jevon, P.; Abdelrahman, A.; Pigadas, N. Management of odontogenic infections and sepsis: An update. Br. Dent. J. 2020, 229, 363-370. [CrossRef]

55. Prasad, K.N.; Mishra, A.M.; Gupta, D.; Husain, N.; Husain, M.; Gupta, R.K. Analysis of microbial etiology and mortality in patients with brain abscess. J. Infect. 2006, 53, 221-227. [CrossRef]

56. Matthews, D. Impact of everyday oral activities on the risk of bacteraemia is unclear. Evid. Based Dent. 2012, 13, 80. [CrossRef] [PubMed]

57. Mark, W.J.; Rossetti, B.J.; Rieken, C.W.; Dewhirst, F.E.; Borisy, G.G. Biogeographyof a human oral microbiome at the micron scale. Proc. Natl. Acad. Sci. USA 2016, 113, E791-E800. [CrossRef]

58. Steinberg, J.P.; Burd, E.M. Other gramnegative and gram-variable bacilli. In Principles and Practice of Infectious Diseases; Mandell, G.L., Bennet, J.E., Dolin, R., Eds.; Elsevier: Amsterdam, The Netherlands, 2009; pp. 3015-3017.

59. Akashi, M.; Tanaka, K.; Kusumoto, J.; Furudoi, S.; Hosoda, K.; Komori, T. Brain Abscess Potentially Resulting from Odontogenic Focus: Report of Three Cases and a Literature Review. J. Maxillofac. Oral Surg. 2017, 16, 58-64. [CrossRef]

60. Pokrowiecki, R.; Mielczarek, A.; Zaręba, T.; Tyski, S. Oral microbiome and peri-implant diseases: Where are we now? Ther. Clin. Risk Manag. 2017, 13, 1529-1542. [CrossRef] [PubMed]

61. Dhir, S. Biofilm and dental implant: The microbial link. J. Indian Soc. Periodontol. 2013, 17, 5-11. [CrossRef] [PubMed]

62. Rapone, B.; Corsalini, M.; Converti, I.; Loverro, M.T.; Gnoni, A.; Trerotoli, P.; Ferrara, E. Does Periodontal Inflammation Affect Type 1 Diabetes in Childhood and Adolescence? A Meta-Analysis. Front. Endocrinol. 2020, 11, 278. [CrossRef]

63. Bahl, R.; Sandhu, S.; Singh, K.; Sahai, N.; Gupta, M. Odontogenic infections: Microbiology and management. Contemp. Clin. Dent. 2014, 5, 307-311. [CrossRef]

64. Sheehan, J.P.; Jane, J.A.; Ray, D.K.; Goodkin, H.P. Brain abscess in children. Neurosurg. Focus. 2008, 24, E6. [CrossRef]

65. Schroeder, B.O.; Bäckhed, F. Signals from the gut microbiota to distant organs in physiology and disease. Nat. Med. 2016, 22, 1079-1089. [CrossRef] [PubMed] 
66. Guarro, J.; Kantarcioglu, A.S.; Horré, R.; Rodriguez-Tudela, J.L.; Cuenca Estrella, M.; Berenguer, J.; de Hoog, G.S. Scedosporium apiospermum: Changing clinical spectrum of a therapy-refractory opportunist. Med. Mycol. 2006, 44, 295-327. [CrossRef]

67. Oberoi, S.S.; Dhingra, C.; Sharma, G.; Sardana, D. Antibiotics in dental practice: How justified are we. Int. Dent. J. 2015, 65, 4-10. [CrossRef]

68. Quaglia, E.; Moscufo, L.; Corsalini, M.; Coscia, D.; Sportelli, P.; Cantatore, F.; De Rinaldis, C.; Rapone, B.; Carossa, M.; Carossa, S. Polyamide vs. silk sutures in the healing of postextraction sockets: A split mouth study. Oral Implantol. 2018, 11, 115-120.

69. Montemurro, N.; Santoro, G.; Marani, W.; Petrella, G. Posttraumatic synchronous double acute epidural hematomas: Two craniotomies, single skin incision. Surg. Neurol. Int. 2020, 11, 435. [CrossRef] [PubMed]

70. Von Graevenitz, A.; Zbinden, R. Actinobacillus, Capnocytophaga, Eikenella, Kingella, Pasteurella, and other fastidious or rarely encountered gram-negative rods. In Manual of Clinical Microbiology; Murray, P.R., Baron, E.J., Eds.; Wiley Online Library: Hoboken, NJ, USA, 2007; pp. 621-636.

71. Rapone, B.; Ferrara, E.; Converti, I.; Loverro, M.; Loverro, M.T.; Gnoni, A.; Petruzzi, M.; Corsalini, M.; Scacco, S.; Di Naro, E. Exploring the role of Fusobacterium nucleatum in preterm birth: A narrative review. Open Access Maced. J. Med. Sci. 2020, 8, 1-7. [CrossRef]

72. Rapone, B.; Ferrara, E.; Montemurro, N.; Converti, I.; Loverro, M.; Loverro, M.T.; Gnoni, A.; Scacco, S.; Siculella, L.; Corsalini, M.; et al. Oral Microbiome and Preterm Birth: Correlation or Coincidence? A Narrative Review. Open Access Maced. J. Med. Sci. 2020, 8, 123-132. [CrossRef]

73. Rapone, B.; Ferrara, E.; Corsalini, M.; Converti, I.; Grassi, F.R.; Santacroce, L.; Topi, S.; Gnoni, A.; Scacco, S.; Scarano, A.; et al. The Effect of Gaseous Ozone Therapy in Conjunction with Periodontal Treatment on Glycated Hemoglobin Level in Subjects with Type 2 Diabetes Mellitus: An Unmasked Randomized Controlled Trial. Int. J. Environ. Res. Public Health 2020, 17, 5467. [CrossRef]

74. Bryan, N.S.; Tribble, G.; Angelov, N. Oral microbiome and nitric oxide: The missing link in the management of blood pressure. Curr. Hypertens. Rep. 2017, 19, 33. [CrossRef] [PubMed]

75. Fanelli, G.N.; Grassini, D.; Ortenzi, V.; Pasqualetti, F.; Montemurro, N.; Perrini, P.; Naccarato, A.G.; Scatena, C. Decipher the Glioblastoma Microenvironment: The First Milestone for New Groundbreaking Therapeutic Strategies. Genes 2021, 12, 445. [CrossRef] [PubMed]

76. Segata, N.; Haake, S.K.; Mannon, P.; Lemon, K.P.; Waldron, L.; Gevers, D.; Huttenhower, C.; Izard, J. Composition of the adult digestive tract bacterial microbiome based on seven mouth surfaces, tonsils, throat and stool samples. Genome Biol. 2012, 13, R42. [CrossRef]

77. Montemurro, N.; Herbet, G.; Duffau, H. Right Cortical and Axonal Structures Eliciting Ocular Deviation During Electrical Stimulation Mapping in Awake Patients. Brain Topogr. 2016, 29, 561-571. [CrossRef] [PubMed]

78. Allan, R. Tunkel, in Mandell, Douglas, and Bennett's Principles and Practice of Infectious Diseases, 8th ed.; Science Direct: Amsterdam, The Netherlands, 2015.

79. Perrini, P.; Pieri, F.; Montemurro, N.; Tiezzi, G.; Parenti, G.F. Thoracic extradural haematoma after epidural anaesthesia. Neurol. Sci. 2010, 31, 87-88. [CrossRef]

80. Corsalini, M.; Di Venere, D.; Sportelli, P.; Magazzino, D.; Ripa, M.; Cantatore, F.; Cagnetta, C.; De Rinaldis, C.; Montemurro, N.; De Giacomo, A.; et al. Evaluation of prosthetic quality and masticatory efficiency in patients with total removable prosthesis: Study of 12 cases. Oral Implantol. 2018, 11, 230-240.

81. Segura-Egea, J.J.; Gould, K.; Şen, B.H.; Jonasson, P.; Cotti, E.; Mazzoni, A.; Sunay, H.; Tjäderhane, L.; Dummer, P.M.H. Antibiotics in Endodontics: A review. Int. Endod. J. 2017, 50, 1169-1184. [CrossRef]

82. Oguntebi, B.; Slee, A.M.; Tanzer, J.M.; Langeland, K. Predominant microflora associated with human dental periapical abscesses. J. Clin. Microbiol. 1982, 15, 964-966. [CrossRef] [PubMed] 